\title{
Corrosion and Wear Properties of Composite Coatings Reinforced with TiB 2 Particles Produced by PTA on Steel Substrate in Different Atmospheres
}

\author{
M. Darabara, ${ }^{1}$ L. Bourithis, ${ }^{2}$ S. Diplas, ${ }^{3}$ and G. D. Papadimitriou ${ }^{1}$ \\ ${ }^{1}$ National Technical University of Athens, School of Mining and Metallurgical Engineering, 9 Iroon Polytechniou Street, \\ 15780 Athens, Greece \\ ${ }^{2}$ Halyvourgiki Steel Plant, National Road Athens-Korinthos 20th km, 19200 Elefsina, Greece \\ ${ }^{3}$ Structural Physics Group, Centre for Materials Science and Nanotechnology (SMN), Gaustadalleen 21, University of Oslo, \\ 0349 Oslo, Norway
}

Correspondence should be addressed to L. Bourithis, bourith@metal.ntua.gr

Received 16 January 2012; Accepted 4 February 2012

Academic Editors: C.-H. Hsu and J. Takadoum

Copyright (C) 2012 M. Darabara et al. This is an open access article distributed under the Creative Commons Attribution License, which permits unrestricted use, distribution, and reproduction in any medium, provided the original work is properly cited.

Titanium diboride $\left(\mathrm{TiB}_{2}\right)$ and titanium carbonitride $(\mathrm{Ti}(\mathrm{C}, \mathrm{N}))$ coatings are widely used as reinforcing materials in applications demanding high corrosion and wear resistance. In this paper, plain carbon steel has been surface alloyed with $\mathrm{TiB}_{2}$ by plasma transferred arc (PTA) technique using two different gas atmospheres. The first metal matrix composite (MMC) is produced with $\mathrm{TiB}_{2}$ particles and argon as shielding and plasma gas. In addition, a mixture of $\mathrm{Ar}$ and $5 \% \mathrm{~N}_{2}$ was used as shielding and plasma gas for producing of second MMC coating. The microstructure of both alloyed layers consists of primary titanium boride particles surrounded by a eutectic matrix, containing ferrite, eutectic boride, and titanium carbonitrides. The presence of these carbonitrides is more intense in the case of the $\mathrm{N}$-enriched alloyed layer, as it was also proved via X-ray Diffraction. The alloyed layers are susceptible to pitting corrosion in $3.5 \% \mathrm{NaCl}$ or $1 \mathrm{~N} \mathrm{H}_{2} \mathrm{SO}_{4}$. The alloyed layer produced with nitrogen mixture gas is slightly more noble than the one produced with pure Ar. The metallic-ferritic matrix corrodes in $6 \% \mathrm{FeCl}_{3} * 6 \mathrm{H}_{2} \mathrm{O}$ leaving TiB 2 particles protruding from the matrix. The wear performance of both $\mathrm{TiB}_{2} \mathrm{MMC}$ depends on the counterbody (tool steel or alumina ball).

\section{Introduction}

Titanium diboride $\left(\mathrm{TiB}_{2}\right)$ and titanium carbonitride $(\mathrm{Ti}(\mathrm{C}$, N)) hard coatings are widely used in applications demanding high corrosion and wear resistance. As titanium has a strong affinity for boron nitrogen and carbon, it combines with these elements in order to form stable titanium borides, nitrides, and carbonitrides, which can be successfully used as reinforcing materials in metal matrix composites (MMCs). In previous studies, $\mathrm{TiN}$ and $\mathrm{Ti}(\mathrm{C}, \mathrm{N})$ coatings are incorporated on various substrates by cathodic arc ion plating process $[1,2]$, physical vapour deposition [3], and plasmaassisted chemical vapour deposition [4]. In addition, $\mathrm{TiB}_{2}$ particles reinforce different substrates by electron beam
$[5,6]$, laser [7-11], or pulsed electrode surfacing [10-12] techniques.

In this study, two different metal matrix composites reinforced with $\mathrm{TiB}_{2}$ are produced on a plain carbon steel substrate by plasma transferred arc (PTA) technique. The first metal matrix composite (MMC) is reinforced with $\mathrm{TiB}_{2}$ particles, while the second one is a nitrogen-enriched $\mathrm{TiB}_{2}$ MMC. The reinforcement with $\mathrm{TiB}_{2}$ particles is achieved by particles of the initial $\mathrm{TiB}_{2}$ powder, whereas the nitrogen is incorporated into the steel surface from the plasma and shielded gas, which is a mixture of $\mathrm{Ar}$ and $5 \% \mathrm{~N}_{2}$. Following their production, the alloyed layers are characterized in respect to their microstructure and their corrosion and wear properties. In a final step, a comparison between the 
TABLE 1: P.T.A. operation parameters.

\begin{tabular}{lcc}
\hline & $\mathrm{TiB}_{2}$ & $\begin{array}{c}\mathrm{TiB}_{2}+\mathrm{N} \\
\text { (Nitrogen-enriched } \mathrm{TiB}_{2} \text { ) }\end{array}$ \\
\hline Current I & $80 \mathrm{~A}$ & $80 \mathrm{~A}$ \\
Scanning speed & $2 \mathrm{~mm} / \mathrm{s}$ & $2 \mathrm{~mm} / \mathrm{s}$ \\
Electrode set back & $0 \mathrm{~mm}$ & $0 \mathrm{~mm}$ \\
Working distance & $2.34 \mathrm{~mm}$ & $2.34 \mathrm{~mm}$ \\
Plasma gas & $0.7 \mathrm{~L} / \mathrm{min} \mathrm{Ar}$ & $0.7 \mathrm{~L} / \mathrm{min} \mathrm{Ar}+5 \% \mathrm{~N}_{2}$ \\
Shielding gas & $7.1 \mathrm{~L} / \mathrm{min} \mathrm{Ar}$ & $7.1 \mathrm{~L} / \mathrm{min} \mathrm{Ar}+5 \% \mathrm{~N}_{2}$ \\
Electrode diameter & $2.4 \mathrm{~mm}$ & $2.4 \mathrm{~mm}$ \\
(W-2\% Ce $\mathrm{O}$ ) & & $2.36 \mathrm{~mm}$ \\
Tip diameter & $2.36 \mathrm{~mm}$ & $2.34 \mathrm{~mm}$ \\
Lateral step & $2.34 \mathrm{~mm}$ & \\
\hline
\end{tabular}

corrosion and wear properties of the produced alloyed layers is achieved.

\section{Experimental}

A plain carbon steel with chemical composition $0.2 \%$ wt C, $1.4 \%$ wt $\mathrm{Mn}$, and $0.3 \%$ wt Si (AISI 1118) was used as the substrate material. Samples of $50 \times 50 \times 14 \mathrm{~mm}$ were cut and polished with abrasive paper down to 1000 grit. Then they were covered with powder of pure $\mathrm{TiB}_{2}$ (grain size: $10 \mu \mathrm{m})$ by mixing the powder with alcohol and applying $0.13 \mathrm{~g}$ per $\mathrm{cm}^{2}$ on the surface of the samples. The covered samples were thereafter heated up to $60^{\circ} \mathrm{C}$ for $0.5 \mathrm{~h}$ for drying and then placed on a copper plate and scanned with plasma transferred arc. The samples were divided in two categories according to the chemistry of plasma and shielding gases used for the treatment. Under the name of " $\mathrm{TiB}_{2}$," the specimens were scanned with pure argon as plasma and shielded gas and under the name of " $\mathrm{TiB}_{2}+\mathrm{N}$," with a mixture of argon and 5\% nitrogen as plasma and shielded gas so as to achieve nitrogen absorption into the alloyed layer. The parameters of the process were carefully selected from a series of preliminary experiments [13] and are given in Table 1. More details regarding the equipment and process used are provided in a previous publication $[14,15]$.

After the treatment, some of the alloyed samples were cut and prepared for examination via optical and electron microscopy associated with EDS microanalysis in the SEM. $\mathrm{X}$-ray diffraction was performed for the alloyed layers at room temperature using a Siemens 5000 diffractometer employing a monochromated $\mathrm{Cu} \mathrm{K} \alpha$ radiation and $2 \theta$ range from $30^{\circ}$ to $90^{\circ}$ with 0.03 degrees steps and $1 \mathrm{~s}$ acquisition time for each step. Microhardness measurements were also provided for the alloyed layer by a microhardness Vickers tester with a load of $200 \mathrm{~g}$ for $15 \mathrm{~s}$.

Samples were also prepared for electrochemical corrosion tests in a cell filled with aqueous solutions of either 3.5\% $\mathrm{NaCl}$ or $1 \mathrm{~N} \mathrm{H}_{2} \mathrm{SO}_{4}$. The corrosion parameters (Ecorr and Icorr) of the alloyed layer were electrochemically determined by cyclic potentiodynamic polarization. Specimens with an exposed area of $1 \mathrm{~cm}^{2}$ were placed in the polarization cell for $1 \mathrm{~h}$ before initiating polarization so as their potential to be stabilized. The cell consisted of a reference platinum electrode and an $\mathrm{AgCl}$ counter electrode, as this is described in ASTM G5-94 standard. A polarization curve for each material was obtained in direct and reverse scans with a potential scan rate of $5 \mathrm{mV} / \mathrm{min}$.

Moreover, samples were also immersed in $6 \% \mathrm{FeCl} 3 *$ $6 \mathrm{H}_{2} \mathrm{O}$ aqueous solution in $50^{\circ} \mathrm{C}$ for $72 \mathrm{~h}$ as this is described in ASTM G48-99 standard for the pitting and crevice corrosion resistance of stainless steels and related alloys. The temperature was held stable for the desirable period by immersing the glasses with the samples into a water bath held at $50^{\circ} \mathrm{C}$. After the period of $72 \mathrm{~h}$, the samples were cleaned and were examined for pittings in stereoscope and scanning electron microscope.

Furthermore, different samples were also prepared for wear testing using a pin-on-disc tribometer. The tests were conducted at room temperature according to ASTM G9995A standard under loads of $4.9 \mathrm{~N}$ and $9.8 \mathrm{~N}$ and sliding velocities ranges from 0.15 to $0.60 \mathrm{~m} / \mathrm{s}$ for a total covered distance for each test of $450 \mathrm{~m}$. The specimens were placed on a rotating disc, whereas a ball of tool steel with $6 \mathrm{~mm}$ diameter and $900 \mathrm{HV}$ hardness or alternatively a $6 \mathrm{~mm}$ ball of alumina with $1900 \mathrm{HV}$ hardness was the stationary counterbody (pin). The friction coefficient was measured continuously through a load cell measuring the tangential force. For every set of conditions, three tests were done for reproducibility of the results. Each sample was examined with optical microscopy and profilometry so as to determine the wear rate and to assess the wear mechanisms.

\section{Results and Discussion}

3.1. Microstructure. Figure 1(a) shows a representative overview of a cross section of the alloyed layers. As it can be seen, the alloyed layers are uniform without cracks or porosities. The isolated dark grey areas observed in this figure correspond to areas dense in $\mathrm{TiB}_{2}$ grains and are present at the extremities of individual PTA passes. The thickness of the melting zone of the $\mathrm{TiB}_{2}$ sample varies between 0.75 and $1 \mathrm{~mm}$, while the $\mathrm{TiB}_{2}+\mathrm{N}$ sample has a thickness, which varies between 0.85 and $1.05 \mathrm{~mm}$.

Both alloyed layers, $\mathrm{TiB}_{2}$ and $\mathrm{TiB}_{2}+\mathrm{N}$, are well bonded to the substrate without cracks or porosities observed in the interface between melting zone and heat-affected zone, as revealed by metallography (Figures 1 (b) and $1(\mathrm{c})$. The heat affected zone exhibits a typical bainitic microstructure and has a thickness of about $1 \mathrm{~mm}$.

Figure 2(a) shows the microstructure of the alloyed layer $\mathrm{TiB}_{2}$, which consists of primary titanium boride particles surrounded by an eutectic matrix, containing ferrite and eutectic boride. The diameter of the primary crystals is about $8 \pm 2 \mu \mathrm{m}$ and that of the eutectic particles smaller than about $1 \mu \mathrm{m}$, as measured with an image analysis program. Primary and eutectic $\mathrm{TiB}_{2}$ particles have polygonal and almost hexagonal shape, characteristic of the hexagonal titanium diboride symmetry. As it can also be seen from Figure 2(a), some zones of the matrix, appearing as dark grey, are almost devoid of eutectic particles and usually come in direct contact with the primary titanium borides. 


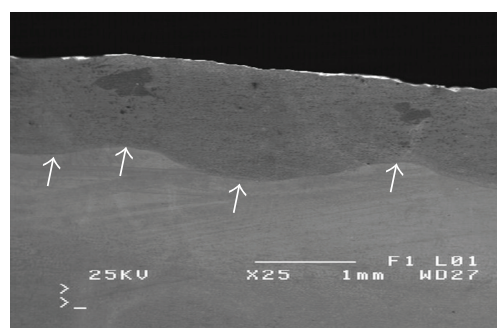

(a)

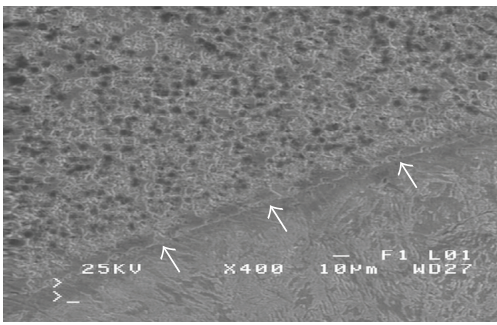

(b)

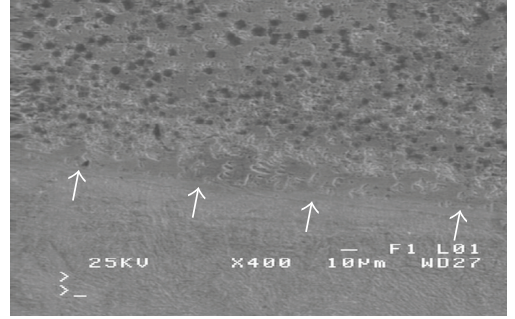

(c)

Figure 1: SEI micrographs of (a) an overview of a cross section of the microstructure of the alloyed layer, (b) and (c) the interface between the alloyed layer $\mathrm{TiB}_{2}$ and $\mathrm{TiB}_{2}+\mathrm{N}$ with the substrate, respectively. (The arrows point the end of melting zone and start of heat-affected zone).

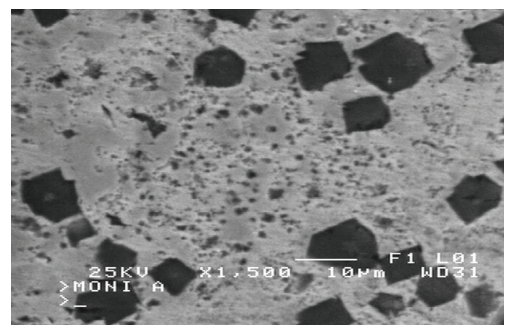

(a)

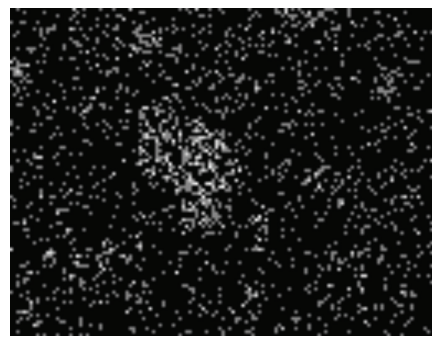

(d)

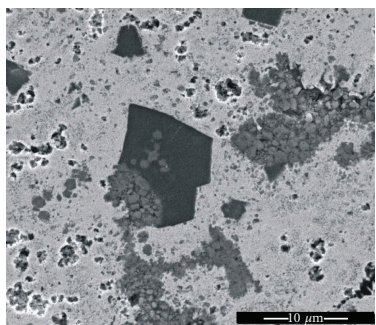

(b)

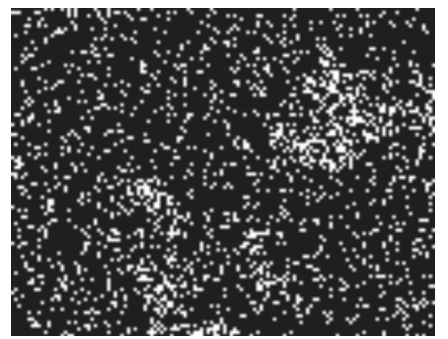

(e)

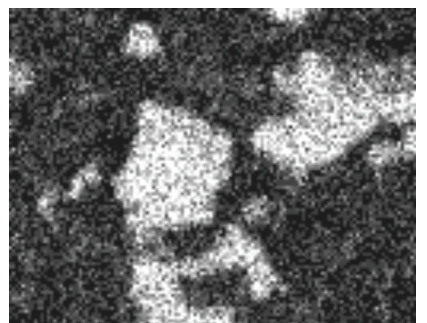

(c)

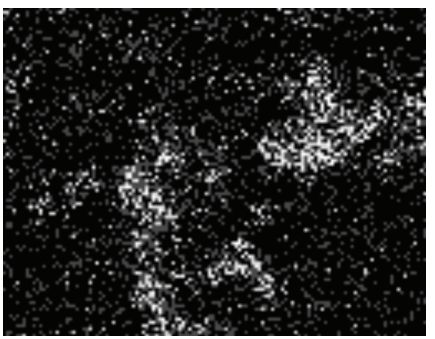

(f)

FIGURE 2: (a) SEI micrograph of the microstructure of the alloyed layer $\mathrm{TiB}_{2}$, (b) higher magnification of the microstructure of layer $\mathrm{TiB}_{2}$, (c-f) elemental mappings of Ti, B, C, and N, respectively, of the region observed in Figure 2(b).

Higher magnification of the microstructure of the $\mathrm{TiB}_{2}$ alloyed layer, Figure 2(b), reveals that primary diboride particles are not homogeneous. In fact, there are some areas inside the primary $\mathrm{TiB}_{2}$ particles that have a light grey colour. The same areas are observed in the rest microstructure. This observation implies that there are compositional differences throughout the $\mathrm{TiB}_{2}$ grains and also the microstructure of the whole alloyed layer. Elemental mappings (Figure 2(c) to 2(f)) of the microstructure observed in Figure 2(b) show that some light grey areas, situated either inside the $\mathrm{TiB}_{2}$ particles or in the rest of the microstructure, are enriched in nitrogen and carbon (Figures 2(e) and 2(f), resp.). Especially inside the $\mathrm{TiB}_{2}$ particle, in regions rich in nitrogen and carbon, there is not boron, indicating the formation of a $\operatorname{Ti}(\mathrm{C}, \mathrm{N})$ compound. The presence of these carbonitrides should be attributed to contamination from carbon coming mainly from the steel substrate and nitrogen coming from titanium diboride powder used as raw material in the process. Nitrogen, carbon, and other contaminants are usually absorbed on the surface of commercial titanium diboride, due to its high specific surface, associated to the fineness of the powder (in our case $10 \mu \mathrm{m}$ ) $[16,17]$.

Figure $3(\mathrm{a})$ shows the microstructure of the $\mathrm{TiB}_{2}+\mathrm{N}$ alloyed layer. As in the case of $\mathrm{TiB}_{2}$ alloyed layer, this layer also consists of primary titanium boride particles surrounded by a eutectic matrix, containing ferrite and eutectic boride. Titanium diboride particles, primary and eutectic, appear as dark contrast particles, and they exhibit prismatic or near hexagonal sections. The diameter of the primary crystals is about $7 \pm 4 \mu \mathrm{m}$ and that of the eutectic particles smaller than about $1 \mu \mathrm{m}$, as measured with an image analysis program.

In general, primary diboride particles are not homogeneous; as in Figure 3(b), compositional differences can be observed into them. In fact, titanium diboride particles include some light grey areas that are enriched with nitrogen and carbon, as this is clarified by both EDS microanalyses on the SEM and elemental mappings. As a matter of fact, high $\mathrm{Ti}$ and $\mathrm{B}$ contents were found on the dark grey area of the primary $\mathrm{TiB}_{2}$ particle, whereas high $\mathrm{N}$ and $\mathrm{C}$ 


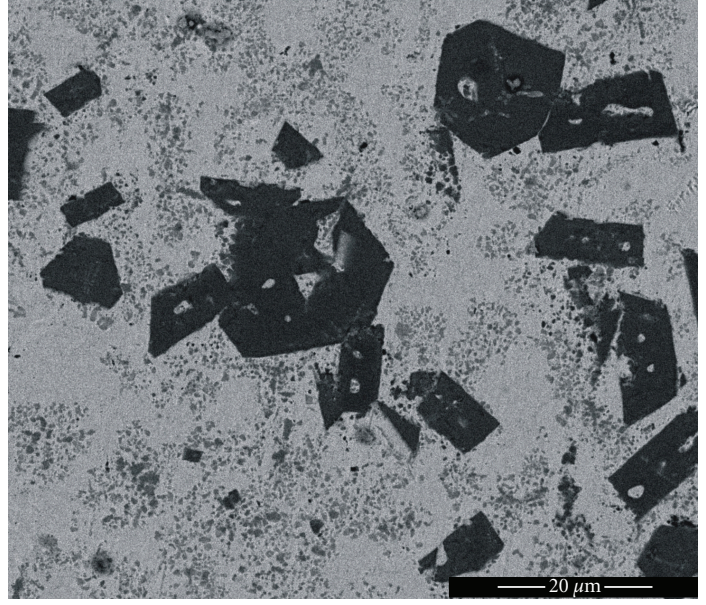

(a)

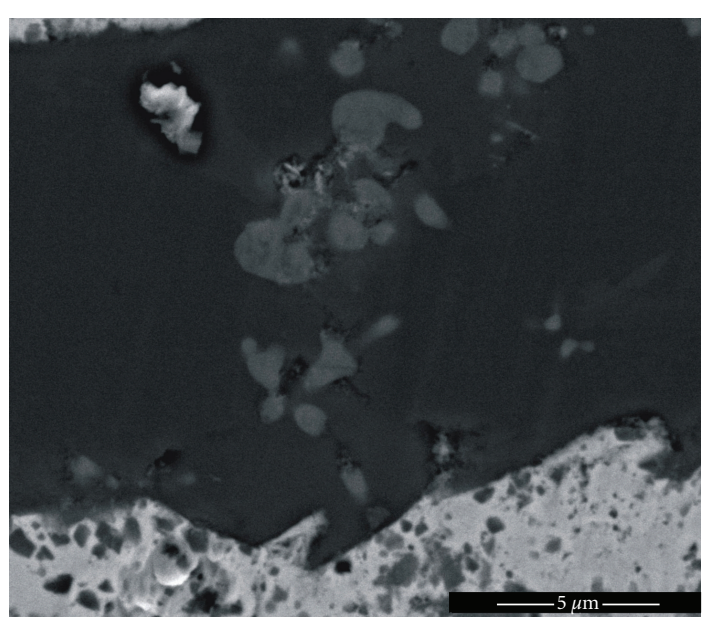

(b)

FIgURE 3: (a) SEI micrograph of the microstructure of the alloyed layer $\mathrm{TiB}_{2}+\mathrm{N}$, (b) high magnification of a region of the layer $\mathrm{TiB}_{2}+\mathrm{N}$ depicting $\mathrm{a} \mathrm{TiB}_{2}$ particle with light grey areas on it enriched in $\mathrm{N}$ and $\mathrm{C}$.

contents were found inside the light grey areas of the same grain (Figure 3(b)). This fact implies again the presence of $\mathrm{Ti}(\mathrm{C}, \mathrm{N})$, as in the case of $\mathrm{TiB}_{2}$ layer. In this coating, the presence of carbonitrides should be attributed to the higher nitrogen contents absorbed by the coating due to the high $\mathrm{N}$ contents in the used plasma and shielded gas. Carbon should also come from the steel substrate.

$\mathrm{X}$-ray diffraction was used so as to clarify further the two different microstructures, Figure 4. X-ray diffraction for the $\mathrm{TiB}_{2}$ alloyed layer reveals the presence of $\alpha$-Fe (or possibly martensite), hexagonal $\mathrm{TiB}_{2}$, and a small amount of titanium carbonitrides, $\mathrm{Ti}(\mathrm{C}, \mathrm{N})$, with cubic symmetry ( $a=4.26 \AA$ ). On the other hand, the XRD pattern of the $\mathrm{TiB}_{2}+\mathrm{N}$ alloyed layer shows peaks of $\alpha$-Fe (or possibly martensite) and peaks of $\mathrm{Ti}(\mathrm{C}, \mathrm{N})$, which are relatively high. It is worth noting that in the second layer, the $\operatorname{Ti}(\mathrm{C}, \mathrm{N})$ peak overtops the ferrite peak. This fact means that a great amount of nitrogen is absorbed by the alloyed layer in order for the titanium to combine with it and to form carbonitrides. These titanium carbonitrides detected by X-ray diffraction presumably coincide with the light grey areas in the SEI images of Figures 2(b) and 3(b). As it can be clearly seen from the XRD patterns, only stable phases such as $\mathrm{TiB}_{2}$ and $\mathrm{Ti}(\mathrm{C}, \mathrm{N})$ are produced with PTA technique, in contrast to laser alloying techniques, leading also to metastable phases with unknown properties [8-11].

3.2. Hardness Measurements. Microhardness tests performed in the melting zone of a cross section of the $\mathrm{TiB}_{2}$ alloyed layer give microhardness, which varies between $550 \mathrm{HV}$ and $650 \mathrm{HV}$. In contrast, in the regions with dense $\mathrm{TiB}_{2}$ grains, the hardness increases and varies between $1200 \mathrm{HV}$ and $1400 \mathrm{HV}$. On the other hand, the microhardness of the melting zone of $\mathrm{TiB}_{2}+\mathrm{N}$ layer with uniform microstructure varies between $600 \mathrm{HV}$ and $700 \mathrm{HV}$, while the microhardness in regions with dense $\mathrm{TiB}_{2}$ grains between $1200 \mathrm{HV}$ and $1400 \mathrm{HV}$.

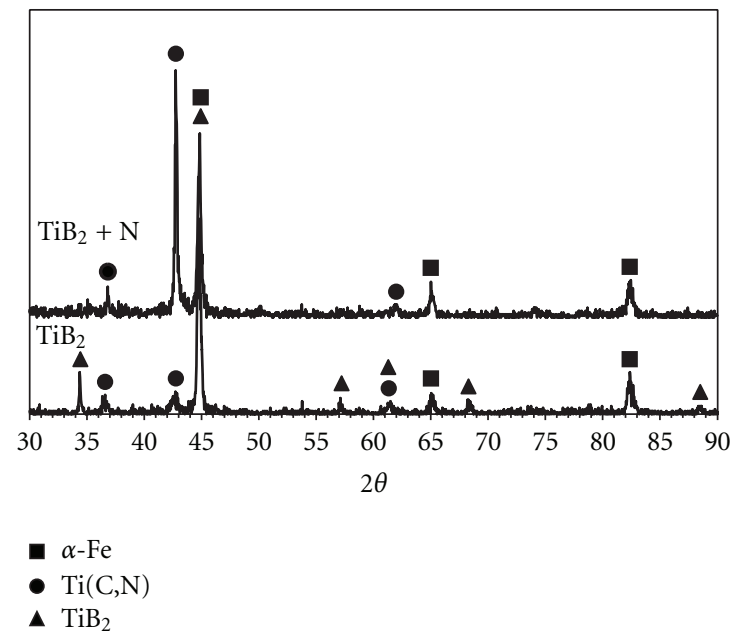

FIGURE 4: X-ray diffraction pattern of the alloyed layers.

The fluctuations in the microhardness within the same area of the alloyed layers must be attributed to the different hardness of the microstructural constituents combined in the composites. As titanium diboride is a ceramic material with high hardness, above $2500 \mathrm{HV}$ [18], it results in the reinforcement of the coated material. Especially in the second layer, the high amount of titanium carbonitrides reinforces even more the ferritic matrix of the coating and increases its hardness. As a matter of fact, the macrohardness of the first alloyed layer is about $600 \mathrm{HV}$ and of the second layer is about $700 \mathrm{HV}$. In areas with dense $\mathrm{TiB}_{2}$ particles, the macrohardness in both layers can reach $1000 \mathrm{HV}$.

3.3. Corrosion. Figures 5(a) and 5(b) represent the cyclic potentiodynamic curves for the plain carbon steel and the alloyed layers in aqueous solutions of $3.5 \% \mathrm{NaCl}$ and $1 \mathrm{~N}$ $\mathrm{H}_{2} \mathrm{SO}_{4}$, respectively. All curves exhibit positive hysteresis, 


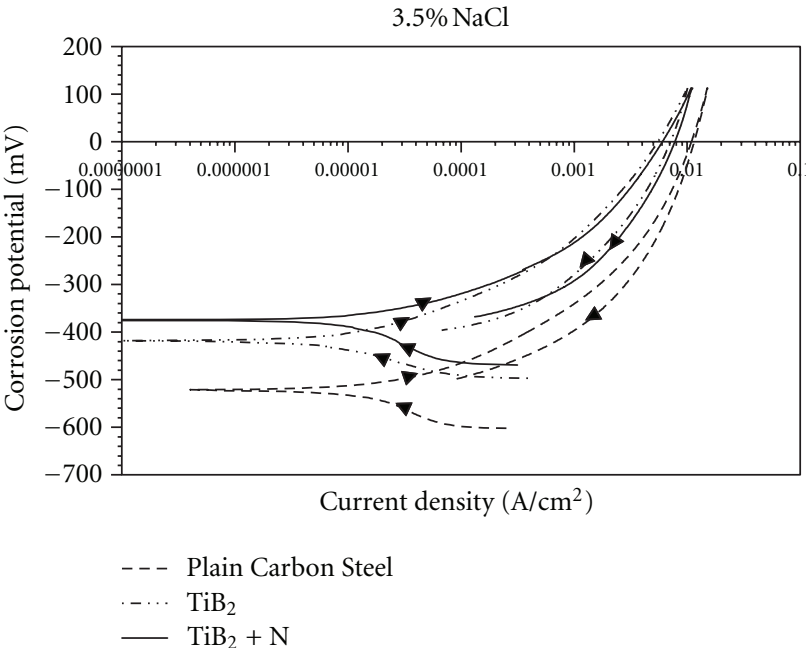

(a)

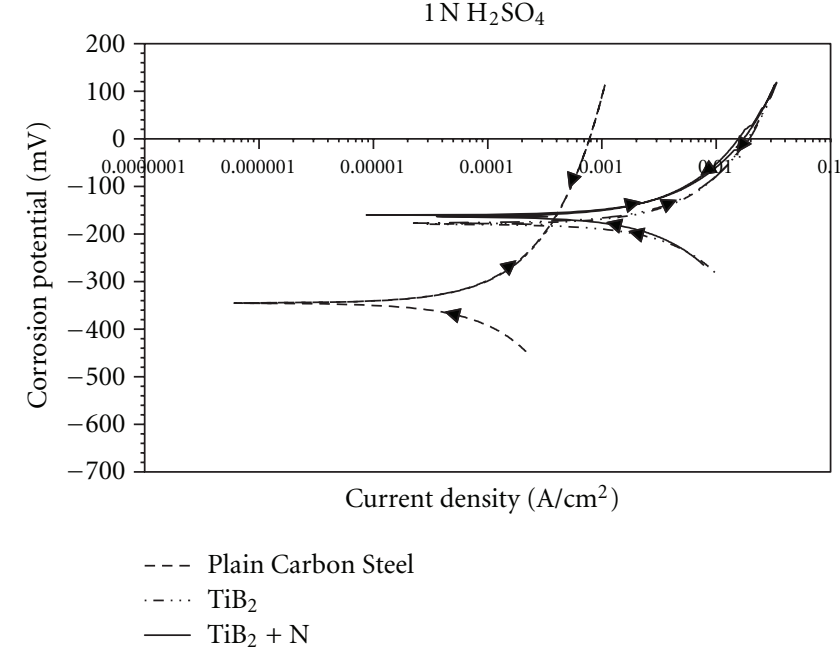

(b)

FIGURE 5: Cyclic polarization curves of the plain carbon steel and the alloyed layers in 3.5\% $\mathrm{NaCl}$ and $1 \mathrm{~N} \mathrm{H}_{2} \mathrm{SO}_{4}$ solutions.

TABle 2: Potentiodynamic parameter values $\left(E_{\text {corr }}, I_{\text {corr }}\right)$ obtained for the alloyed layers.

\begin{tabular}{lcccc}
\hline & \multicolumn{2}{c}{$3.5 \% \mathrm{NaCl}$} & \multicolumn{2}{c}{$1 \mathrm{~N} \mathrm{H}_{2} \mathrm{SO}_{4}$} \\
& $E_{\text {corr }}(\mathrm{mV})$ & $\begin{array}{c}I_{\text {corr }} \\
\left(\mathrm{A} / \mathrm{cm}^{2}\right)\end{array}$ & $E_{\text {corr }}(\mathrm{mV})$ & $\begin{array}{c}I_{\text {corr }} \\
\left(\mathrm{A} / \mathrm{cm}^{2}\right)\end{array}$ \\
\hline Plain carbon steel & -524 & $3 * 10^{-6}$ & -347 & $4 * 10^{-6}$ \\
$\mathrm{TiB}_{2}$ & -420 & $9 * 10^{-7}$ & -179 & $3 * 10^{-4}$ \\
$\mathrm{TiB}_{2}+\mathrm{N}$ & -374 & $9 * 10^{-7}$ & -164 & $3 * 10^{-4}$ \\
\hline
\end{tabular}

given that in the reverse anodic scan the current density is higher than that for the forward scan. This fact confirms that both steel and the alloyed layers are susceptible to pitting corrosion.

According to Figure 5(a) and Table 2, the alloyed layers $\mathrm{TiB}_{2}$ and $\mathrm{TiB}_{2}+\mathrm{N}$ in $3.5 \% \mathrm{NaCl}$ are more noble than carbon steel, as they both have higher corrosion potential $\left(E_{\text {corr }}\right)$. Moreover, they exhibit lower current densities $\left(I_{\text {corr }}\right)$, and thus they do not corrode as fast as plain carbon steel does. They do not also have a passive region observed in the polarization curve, as the potential continuously increases as the current increases too.

Similarly, the alloyed layers are nobler than steel in $1 \mathrm{~N}$ $\mathrm{H}_{2} \mathrm{SO}_{4}$ solution, as they have higher $E_{\text {corr }}$ than that of steel. The main difference between the two materials lies on their current density values that in the case of the alloyed layers seems to be a little higher than the plain steel. This fact implies that although the layers are nobler than steel, when they will begin to corrode, they will exhibit higher corrosion rates. In addition, all the tested materials do not passivate in $1 \mathrm{~N} \mathrm{H}_{2} \mathrm{SO}_{4}$. A similar result was also found in the work of Munro [18] who attributed the absence of $\mathrm{TiB}_{2}$ passivation to the presence of the white film of tetravalent oxide titanium $\left(\mathrm{TiO}_{2} * \mathrm{H}_{2} \mathrm{O}\right)$ coming from the dissolution of $\mathrm{TiB}_{2}$.

The alloyed layer $\mathrm{TiB}_{2}+\mathrm{N}$ has slightly better corrosion behaviour than the alloyed layer $\mathrm{TiB}_{2}$, as it has higher corrosion potential values in the two tested solutions. As a matter of fact, following the corrosion experiments of both layers in $6 \%$ wt $\mathrm{FeCl}_{3} * 6 \mathrm{H}_{2} \mathrm{O}$, the alloyed layer $\mathrm{TiB}_{2}+$ $\mathrm{N}$ was found again more resistant. Figures $6(\mathrm{a})$ and $6(\mathrm{~b})$ present the surface of the coating $\mathrm{TiB}_{2}$, while Figures $6(\mathrm{c})$ and $6(\mathrm{~d})$ present the corroded surface of the layer $\mathrm{TiB}_{2}+$ $\mathrm{N}$. As it can be seen from the first two figures, layer $\mathrm{TiB}_{2}$ is totally detached from the substrate, leaving the steel substrate susceptible to corroded solutions. On the contrary, layer $\mathrm{TiB}_{2}+\mathrm{N}$ is not totally detached from the substrate but presents cracks and corrosion signs. In fact, $\mathrm{TiB}_{2}$ particles are protruding from the matrix, which has been highly corroded (Figure 6(d)).

Generally speaking, the corrosion resistance of the alloyed layers is not highly improved by the $\mathrm{TiB}_{2}$ particles, because of the metallic ferritic matrix, which is considerably susceptible to pitting corrosion. This is also confirmed from the observation of the alloyed layer after corrosion experiments in the scanning electron microscope (Figure 6), where $\mathrm{TiB}_{2}$ particles are protruding from the ferritic matrix that has been consumed due to the corrosive environments. The presence of the metallic binder in the alloyed layers decreases the corrosion resistance, as it has also been studied elsewhere $[19,20]$.

3.4. Pin on Disk Wear Testing. Figure 7(a) presents the wear rate of the alloyed layer $\mathrm{TiB}_{2}$ against the tool steel ball that is of the order $10^{-5} \mathrm{~mm}^{3}$ volume loss per $\mathrm{m}$ of sliding distance. Increasing the sliding speed, the wear rate decreases slightly for the two applied loads, as it has also been found in another investigation [21]. At the same time, for higher applied loads, the wear rate increases. In addition, the wear rate for the tests with the $\mathrm{Al}_{2} \mathrm{O}_{3}$ ball, presented in Figure 7(b), is of the order of $10^{-4} \mathrm{~mm}^{3}$ volume loss per $\mathrm{m}$ of sliding distance. In this case, the wear rate increases with increasing applied load, but it is not been affected by sliding speed. 


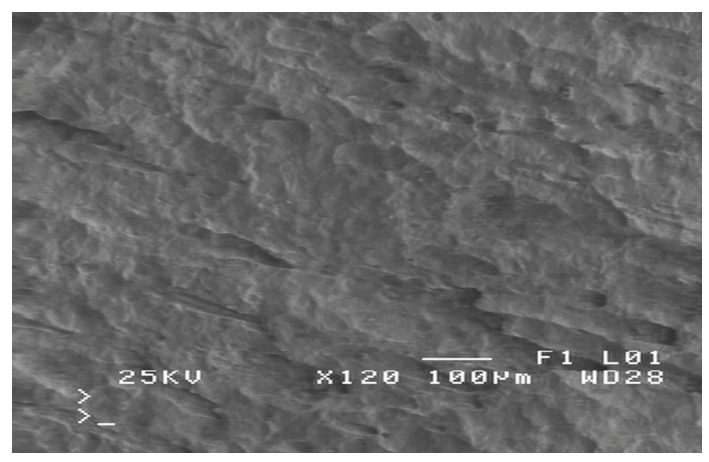

(a)

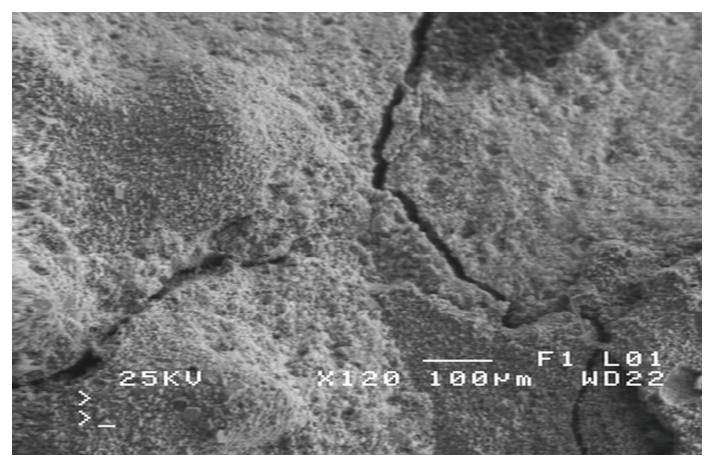

(c)

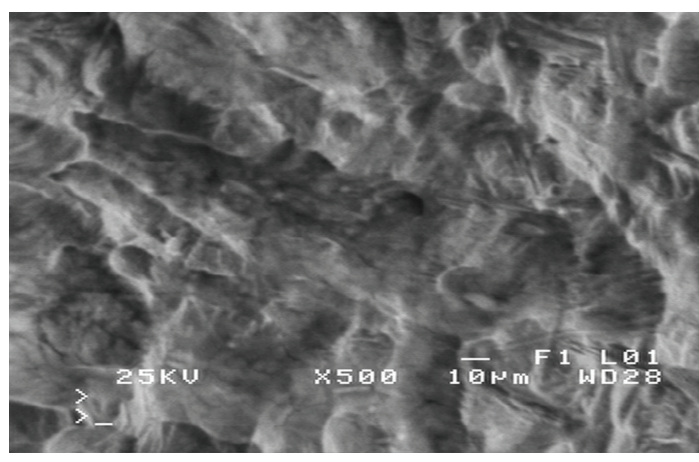

(b)

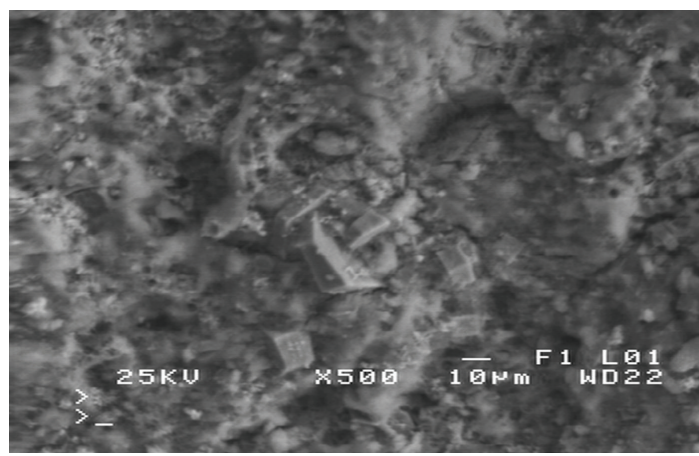

(d)

FIGURE 6: SEI micrographs of the exposed surfaces of the alloyed layers to $\mathrm{FeCl}_{3}$ solution after corrosion experiments: (a, b) alloyed layer $\mathrm{TiB}_{2}$ and $(\mathrm{c}, \mathrm{d})$ alloyed layer $\mathrm{TiB}_{2}+\mathrm{N}$.

The wear tracks after the tests with the tool steel ball are covered by a gray layer of oxide powder, Figure 7(c), consisting oxygen, titanium, and iron, as this was confirmed by EDS microanalyses on the SEM. Examination of the worn surface of the tool steel ball reveals no sign of oxides or material transfer to the ball from the wear track. On the contrary, it is very clean and presents abrasion scars to the direction of movement. Moreover, for the pair, alloyed layer$\mathrm{Al}_{2} \mathrm{O}_{3}$ ball, there is no sign of an oxide layer formed or material stack on the surface of the track. The matrix present deep scars and abrasive marks, while $\mathrm{TiB}_{2}$ particles are protruding from the matrix, Figure $7(\mathrm{~d})$. The worn surface of the $\mathrm{Al}_{2} \mathrm{O}_{3}$ ball is partially covered with a black powder, apparently steel debris stack on the ball, and it has hills on its surface that act as cutting points for the alloyed layer. The high hardness of the alumina compared to the relative softer matrix of the alloyed layer favors the cutting action.

The friction coefficient for the pair, alloyed layer $\mathrm{TiB}_{2}-$ steel, was measured throughout the experiments and very stably attained the value of $0.12 \pm 0.01$. This is a very low friction coefficient compared with that found elsewhere [11]. The oxide layer found on the surface of the wear tracks in combination with the decrease of the wear rate with increasing sliding speed and the low friction coefficient dominating the coating may be attributed leads to an active oxidation mechanism $[22,23]$. On the contrary, the friction coefficient for the pair, alloyed layer $\mathrm{TiB}_{2}$-alumina ball, is $0.59 \pm 0.05$ and is considerably higher than the one measured for the couple alloyed layer-tool steel. A similar friction coefficient was found in another work [24].

The wear rate of the pair, alloyed layer $\mathrm{TiB}_{2}+\mathrm{N}$-tool steel ball, is presented in Figure 8(a). As it can be seen, the wear rate is of the order of $10^{-4} \mathrm{~mm}^{3}$ volume loss per $\mathrm{m}$ of sliding distance, while it increases for higher applied loads and sliding speed values. The wear tracks after the tests exhibit plastic deformation and the presence of an oxide layer, while some areas have been removed from the alloyed layer. This removed material has been stuck on the steel ball, as according to EDS microanalyses on the SEM, oxygen, titanium, and iron found on the balls. Similarly, the wear rate of the pair, alloyed layer $\mathrm{TiB}_{2}+\mathrm{N}-\mathrm{Al}_{2} \mathrm{O}_{3}$ ball, presented in Figure $8(\mathrm{~b})$, are again of the order of $10^{-4} \mathrm{~mm}^{3}$ volume loss per $\mathrm{m}$ of sliding distance. As it can be seen, increasing applied load and increasing sliding speed result in increasing wear rate. The wear tracks after the tests present signs of oxide, Figure 8(c), and severe plastic deformation, Figure 8(d). The wear spot of the $\mathrm{Al}_{2} \mathrm{O}_{3}$ ball is partially covered with steel debris.

The friction coefficient measured throughout almost all the experiments with tool steel ball was not stable. The plastic deformation in combination with material transfer from the alloyed layer to the ball leads to a relatively high friction coefficient (between 0.45 and 0.6). Similarly, for the pair layer-alumina, the friction coefficient did not remain stable and was fluctuated between the values measured for the couple alloyed layer-tool steel. 


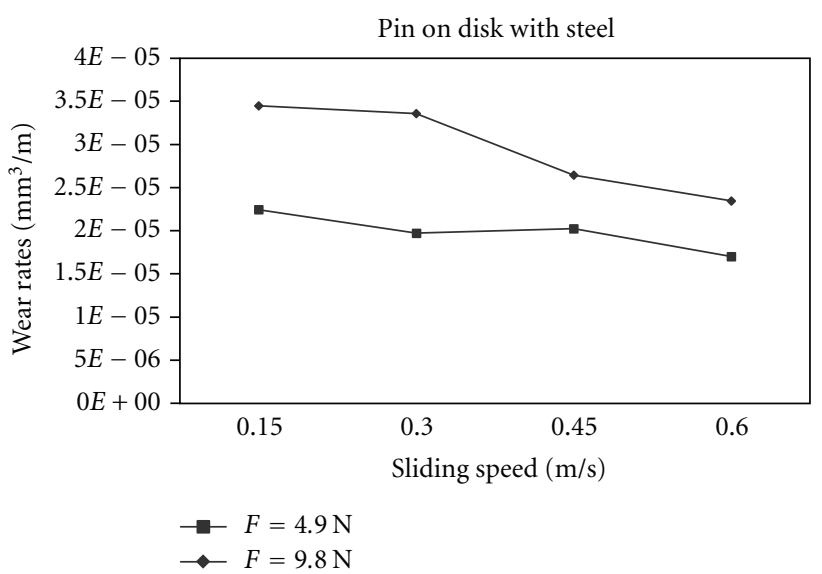

(a)

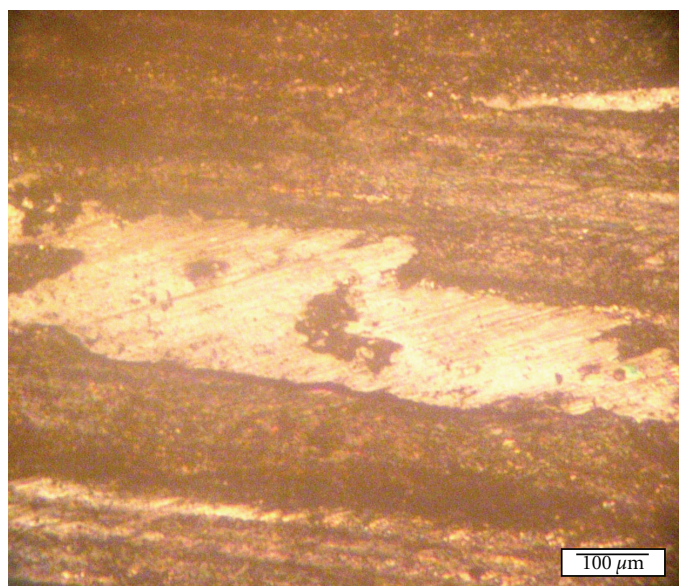

(c)

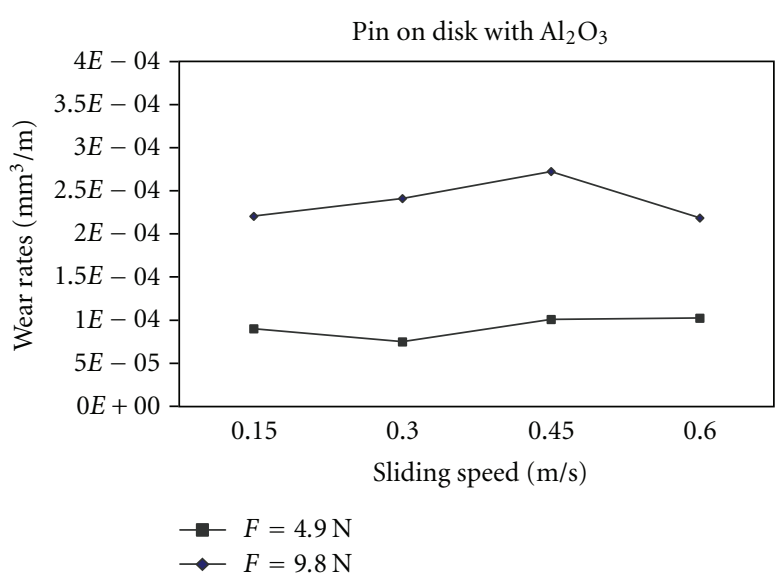

(b)

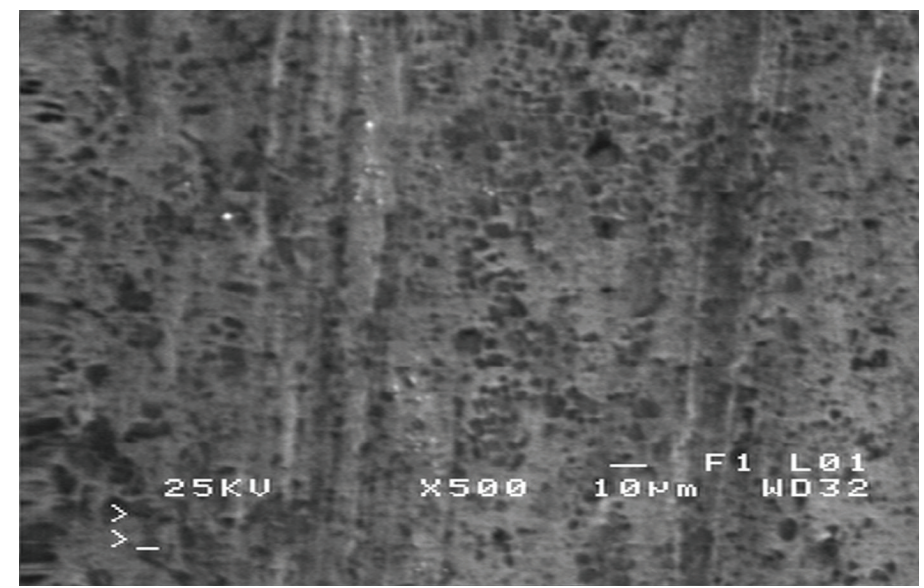

(d)

Figure 7: (a) Wear rates of the pair-alloyed layer $\mathrm{TiB}_{2}$-tool steel ball, (b) wear rates of the pair-alloyed layer $\mathrm{TiB}_{2}-\mathrm{Al}_{2} \mathrm{O}_{3}$ ball, (c) wear track for the pair-alloyed layer $\mathrm{TiB}_{2}$-tool steel ball, (d) SEM micrograph of the wear track for the pair-alloyed layer-alumina ball showing the plastic deformation of the alloyed layer and the presence of $\mathrm{TiB}_{2}$ particles protruding from the matrix.

Comparing the two different tribosystems for the alloyer layer $\mathrm{TiB}_{2}$, it can be postulated that the wear performance of the $\mathrm{TiB}_{2}$ MMC depends on the counterbody, since both wear mechanism and friction coefficient are quite different. The alumina ball, as it is harder than the steel ball, causes more damage to the alloyed layer but also alters the wear mechanism involved leading to higher friction coefficient. On the contrary, comparing the two different tribosystems for the alloyed layer $\mathrm{TiB}_{2}+\mathrm{N}$, it gets the conclusion that the wear performance of the nitrogen-rich $\mathrm{TiB}_{2} \mathrm{MMC}$ is characterized by plastic deformation and formation of oxides for both tribosystems. Especially for the alloyed layertool steel system, the alloyed layer in every test condition underwent plastic deformation with detachment of material transferred and stuck to the ball surface.

\section{Conclusions}

(i) Through a nitrogen-rich plasma and shielded gas of the Plasma Transferred Arc technique, alloyed layers enriched in nitrogen can be produced. Moreover, the
PTA alloying technique can produce metal matrix composites with $\mathrm{TiB}_{2}$ as reinforcing material.

(ii) Both alloyed layers produced, $\mathrm{TiB}_{2}$ and $\mathrm{TiB}_{2}+\mathrm{N}$, are uniform, without cracks, and have a thickness of about $1 \mathrm{~mm}$.

(iii) The microstructures obtained consist of primary titanium diboride particles in an eutectic mixture of iron and eutectic boride particles. Titanium carbonitrides are also present in both alloyed layers with $\mathrm{Ar}$ or $\mathrm{Ar}$ $+5 \% \mathrm{~N}_{2}$. In the first layer, carbon comes from the substrate, while carbon and nitrogen are impurities of the titanium diboride powder used in the process. In the second layer, carbon also originates from the substrate, and nitrogen mainly from the $\mathrm{N}_{2}$ of the plasma and shielded gases.

(iv) Both alloyed layers are susceptible to pitting corrosion in $3.5 \% \mathrm{NaCl}$ and $1 \mathrm{~N} \mathrm{H}_{2} \mathrm{SO}_{4}$. The alloyed layers produced with mixture of $\mathrm{Ar}+5 \% \mathrm{~N}_{2}$ are slightly more noble than the one produced with pure Ar. 


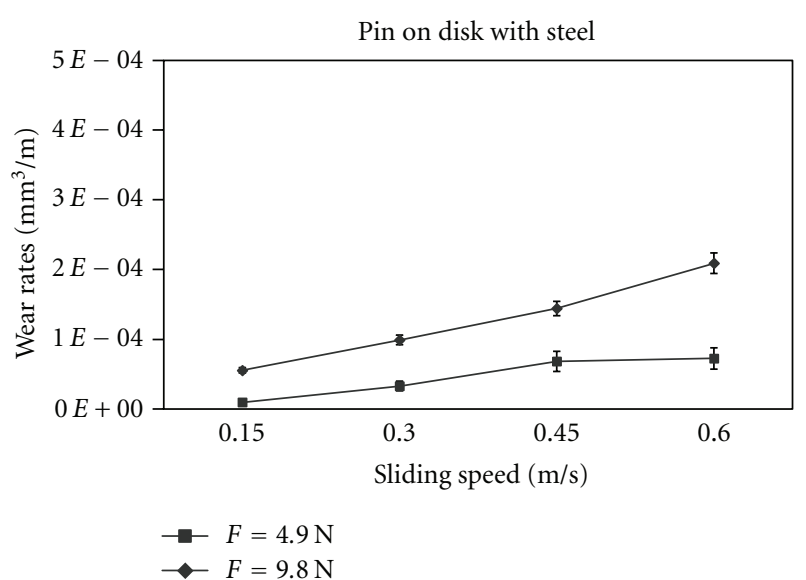

(a)

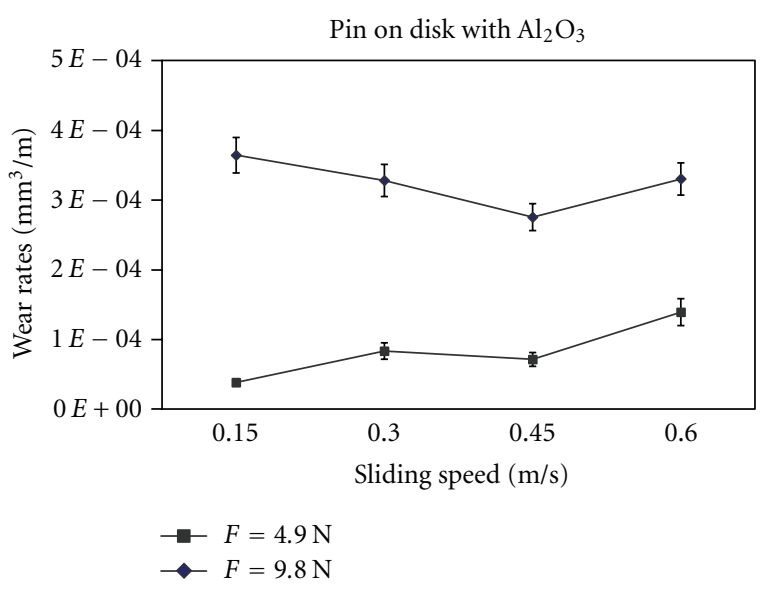

(b)

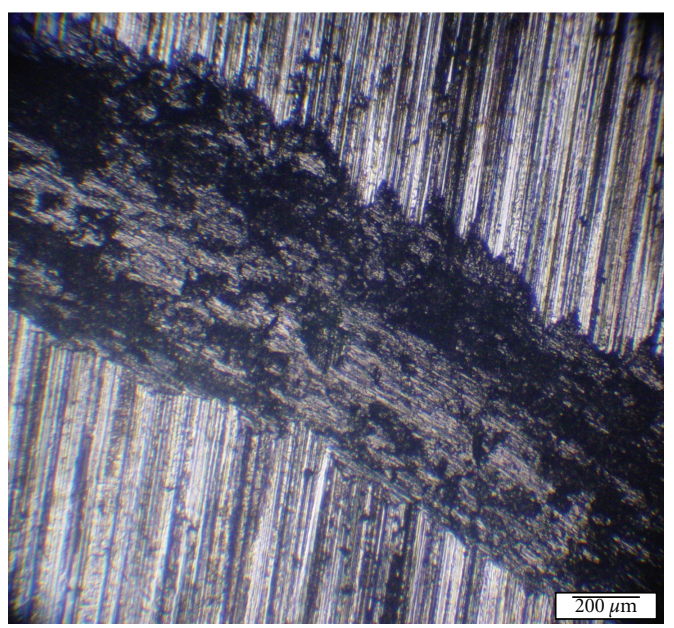

(c)

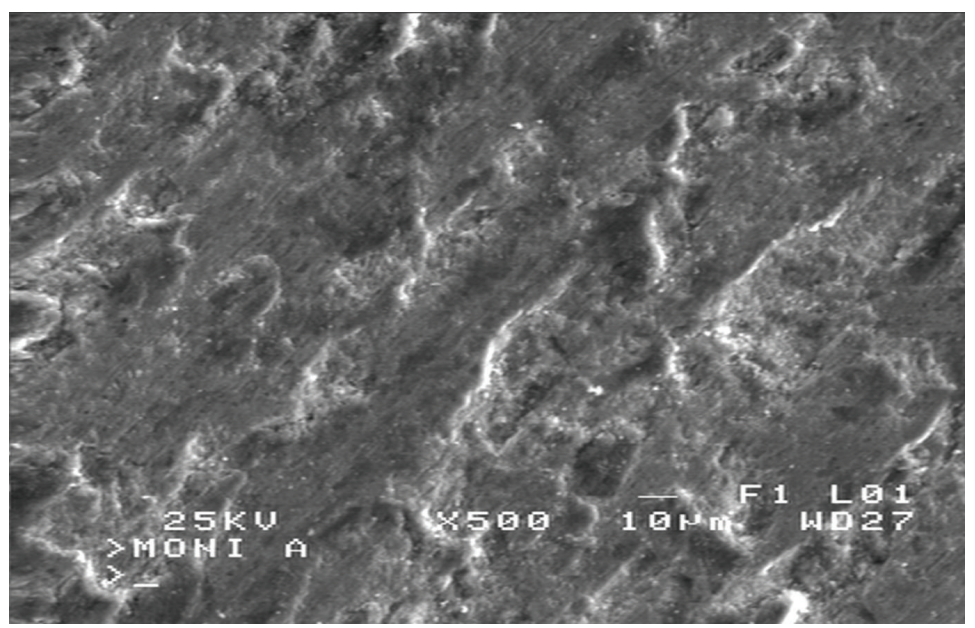

(d)

FIgURE 8: (a) Wear track for the pair alloyed layer $\mathrm{TiB}_{2}+\mathrm{N}$-tool steel ball, (b) wear track for the pair alloyed layer $\mathrm{TiB}_{2}+\mathrm{N}$-alumina ball, (c) wear track for the pair alloyed layer $\mathrm{TiB}_{2}$-tool steel ball, (d) SEM micrograph of the wear track for the pair alloyed layer-alumina ball showing the plastic deformation of the alloyed layer and the presence of $\mathrm{TiB}_{2}$ particles protruding from the matrix.

(v) The corrosion resistance of the alloyed layers in $6 \%$ wt $\mathrm{FeCl}_{3} * 6 \mathrm{H}_{2} \mathrm{O}$ is not highly improved by $\mathrm{TiB}_{2}$ particles, because of the metallic-ferritic matrix, which is considerably susceptible to corrosion.

(vi) The wear rate of the coupling alloyed layer $\mathrm{TiB}_{2}-$ tool steel is of the order of $10^{-5} \mathrm{~mm}^{3} / \mathrm{m}$, while for the coupling alloyed layer-alumina is of the order of $10^{-4} \mathrm{~mm}^{3} / \mathrm{m}$. On the contrary, the wear rate of the coupling alloyed layer $\mathrm{TiB}_{2}+\mathrm{N}$-tool steel or alumina is of the order of $10^{-4} \mathrm{~mm}^{3} / \mathrm{m}$.

(vii) The wear mechanism observed for the alloyed layer $\mathrm{TiB}_{2}$ against tool steel or alumina ball is different, although they are tested under the same conditions. On the other hand, the wear mechanism of the alloyed layer $\mathrm{TiB}_{2}+\mathrm{N}$ against a tool steel or an alumina ball is similar.

(viii) Under the wear conditions examined here alloyed layers undergo severe plastic deformation with, in some cases, detachment of material from the surface that transfers and stick on the ball surface. In addition, for the tribosystem $\mathrm{TiB}_{2}$ alloyed layer against tool steel, there is evidence of an active oxidation mechanism, which leads to decrease in wear rate and low-friction coefficient.

\section{References}

[1] Y. Y. Guu and J. F. Lin, "Comparison of the tribological characteristics of titanium nitride and titanium carbonitride coating films," Surface and Coatings Technology, vol. 85, no. 3, pp. 146-155, 1996.

[2] Y. Y. Guu and J. F. Lin, "Analysis of wear behaviour of titanium carbonitride coatings," Wear, vol. 210, no. 1-2, pp. 245-254, 1997.

[3] B. Podgornik, S. Hogmark, and O. Sandberg, "Influence of surface roughness and coating type on the galling properties of coated forming tool steel," Surface and Coatings Technology, vol. 184, no. 2-3, pp. 338-348, 2004.

[4] C. Pfohl, K. T. Rie, M. K. Hirschfeld, and J. W. Schultze, "Evaluation of the corrosion behaviour of wear-resistant PACVD 
coatings," Surface and Coatings Technology, vol. 112, no. 1-3, pp. 114-117, 1999.

[5] K. Euh, J. Lee, S. Lee, Y. Koo, and N. J. Kim, "Microstructural modification and hardness improvement in boride/Ti-6Al-4V surface-alloyed materials fabricated by high-energy electron beam irradiation," Scripta Materialia, vol. 45, no. 1, pp. 1-6, 2001.

[6] K. Euh, S. Lee, and K. Shin, "Microstructure of $\mathrm{TiB}_{2} /$ carbon steel surface-alloyed materials fabricated by high-energy electron beam irradiation," Metallurgical and Materials Transactions A, vol. 30, no. 12, pp. 3143-3151, 1999.

[7] P. Gopalakrishnan, P. Shankar, R. V. Subba Rao, M. Sundar, and S. S. Ramakrishnan, "Laser surface modification of low carbon borided steels," Scripta Materialia, vol. 44, no. 5, pp. 707-712, 2001.

[8] A. Agarwal and N. B. Dahotre, "Laser surface engineering of steel for hard refractory ceramic composite coating," International Journal of Refractory Metals and Hard Materials, vol. 17, no. 4, pp. 283-293, 1999.

[9] A. Agarwal, L. R. Katipelli, and N. B. Dahotre, "Elevated temperature oxidation of laser surface engineered composite boride coating on steel," Metallurgical and Materials Transactions A, vol. 31, no. 2, pp. 461-473, 2000.

[10] A. Agarwal and N. B. Dahotre, "Synthesis of boride coating on steel using high energy density processes: comparative study of evolution of microstructure," Materials Characterization, vol. 42, no. 1, pp. 31-44, 1999.

[11] A. Agarwal and N. B. Dahotre, "Comparative wear in titanium diboride coatings on steel using high energy density processes," Wear, vol. 240, no. 1-2, pp. 144-151, 2000.

[12] A. Agarwal and N. B. Dahotre, "Pulse electrode deposition of superhard boride coatings on ferrous alloy," Surface and Coatings Technology, vol. 106, no. 2-3, pp. 242-250, 1998.

[13] L. Bourithis and G. D. Papadimitriou, "Study of the operational parameters of plasma transferred arc melting and modelling of the process," Science and Technology of Welding and Joining, vol. 10, no. 6, pp. 673-680, 2005.

[14] L. Bourithis, S. Papaefthymiou, and G. D. Papadimitriou, "Plasma transferred arc boriding of a low carbon steel: microstructure and wear properties," Applied Surface Science, vol. 200, no. 1-4, pp. 203-218, 2002.

[15] M. Darabara, G. D. Papadimitriou, and L. Bourithis, "Synthesis of $\mathrm{TiB}_{2}$ metal matrix composite on plain steel substrate: microstructure and wear properties," Materials Science and Technology, vol. 23, no. 7, pp. 839-846, 2007.

[16] L. S. Sigl and K. A. Schwetz, "TiB ${ }_{2}$-based cemented borides. A new generation of hardmetals," Powder Metallurgy International, vol. 23, no. 4, pp. 221-224, 1991.

[17] L. Ottavi, C. Saint-Jours, N. Valignant, and C. H. Allibert, "Phase equilibria and solidification of Fe-Ti-B alloys in the region close to $\mathrm{Fe}^{-\mathrm{TiB}_{2}}$," Materials Research and Advanced Techniques, vol. 83, no. 2, pp. 80-83, 1992.

[18] R. G. Munro, "Material properties of titanium diboride," Journal of Research of the National Institute of Standards and Technology, vol. 105, no. 5, pp. 709-720, 2000.

[19] B. S. Coving Jr., S. D. Cramer, J. P. Carter, and D. Schlain, "Corrosion of titanium diboride," Journal of The Less-Common Metals, vol. 41, no. 2, pp. 211-224, 1975.

[20] V. A. Lavrenko, V. A. Shvets, A. P. Umanskii, A. B. Belykh, V. M. Adeev, and V. N. Talash, "Electrolytic corrosion of titanium carbonitride composites," Powder Metallurgy and Metal Ceramics, vol. 43, no. 1-2, pp. 62-66, 2004.

[21] S. Chao, N. Liu, Y. Yuan et al., "Microstructure and mechanical properties of ultrafine $\mathrm{Ti}(\mathrm{CN})$-based cermets fabricated from nano/submicron starting powders," Ceramics International, vol. 31, no. 6, pp. 851-862, 2005.

[22] T. F. J. Quinn, D. M. Rowson, and J. L. Sullivan, "Application of the oxidational theory of mild wear to the sliding wear of low alloy steel," Wear, vol. 65, no. 1, pp. 1-20, 1980.

[23] T. F. J. Quinn, J. L. Sullivan, and D. M. Rowson, "Origins and development of oxidational wear at low ambient temperatures," Wear, vol. 94, no. 2, pp. 175-191, 1984.

[24] M. H. Staia, A. Fragiel, M. Cruz et al., "Characterization and wear behavior of pulsed electrode surfacing coatings," Wear, vol. 250-251, no. 2, pp. 1051-1060, 2001. 

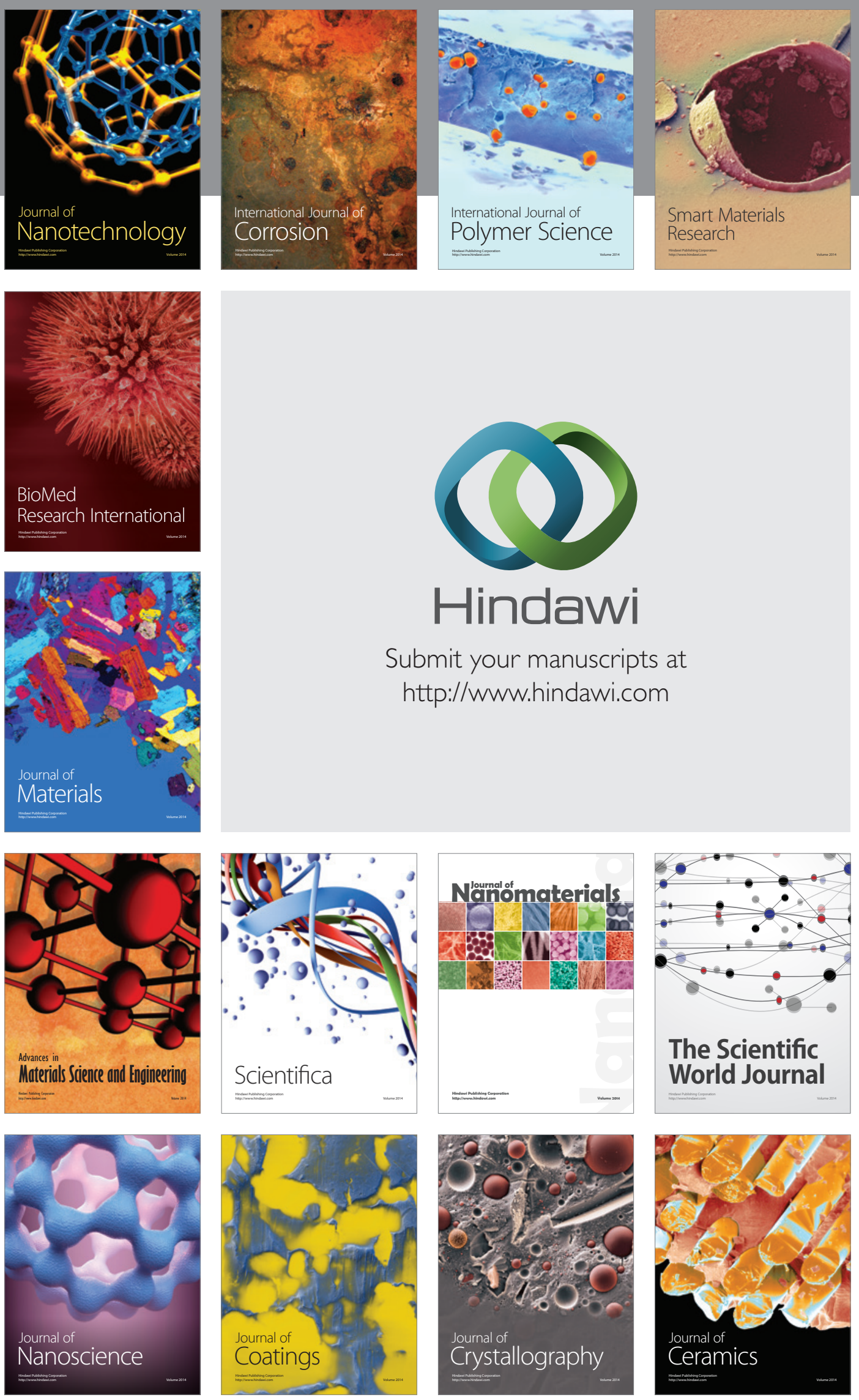

The Scientific World Journal

Submit your manuscripts at

http://www.hindawi.com

\section{World Journal}

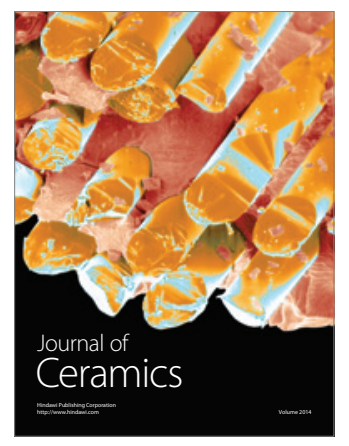

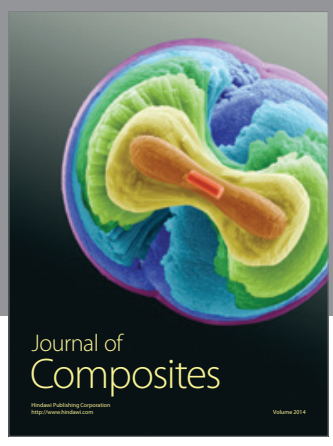
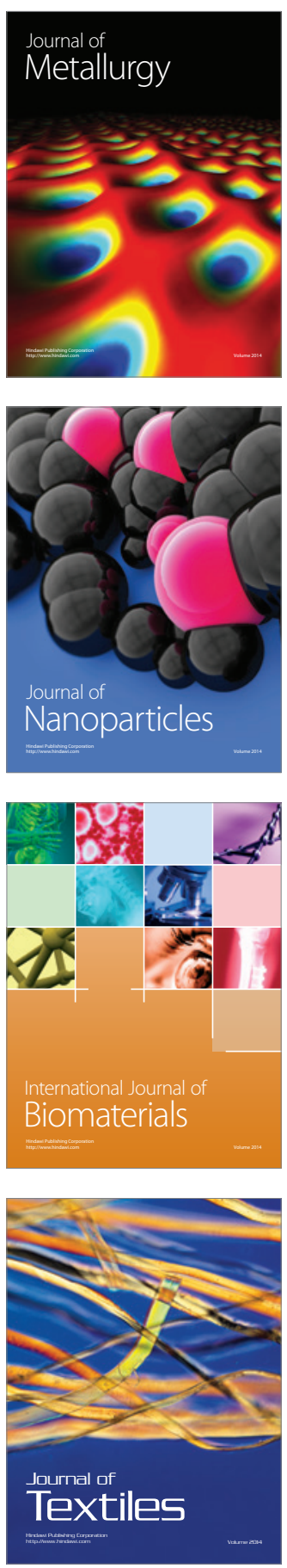